\title{
RELATIVE ABUNDANCE AND DIVERSITY OF ODONATA IN AN IRRIGATED RICE FIELD OF MADURAI, TAMIL NADU
}

\author{
M. Kandibane ${ }^{1}$, S. Raguraman ${ }^{2}$ and N. Ganapathy ${ }^{2}$
}

${ }^{1}$ Krishi Vigyan Kendra, Vriddhachalam, Tamil Nadu 606001, India

${ }^{2}$ Agricultural College and Research Institute, Madurai, Tamil Nadu 625104, India

\begin{abstract}
A total of 12 taxa of odonata of nine Anisoptera and three Zygoptera were recorded during kharif 2000 in an irrigated rice field of Madurai. Among anisopterans, four species, Pantala flavescens (Fabricius), Diplocodes trivialis (Rambur), Crocothemis servilia (Drury) and Tramea limbata (Desjardins) were dominant. Among zygopterans, Agriocnemis femina femina Brauer was the dominant species recorded in weeded and partially weeded ecosystems. The four species of dragonflies and one species of damselfly had comparatively more abundance in partially weeded rice ecosystem than in weeded rice ecosystem. Rare species like Orthetrum sabina (Drury), Rhyothemis variegata (Linnaeus), Neurothemis tullia (Drury), Anax guttatus (Burmeister) and Trithemis $s p$. with fewer individuals occurred only at the tillering stage of crop growth.
\end{abstract}

\section{KEYWoRDS}

Anisoptera, diversity, Madurai, Odonata, relative abundance, rice ecosystem, weeding, Zygoptera

Odonata is the largest insect order, which is entirely predaceous in rice ecosystem. Both naiads and adults are voracious predators on other insects. Gunathilagaraj et al. (1999) recorded 16 species of Odonata in rice fields of Coimbatore, Tamil Nadu, India. Barrion and Litsinger (1994) listed 14 species of Odonata in rice fields of Asia and Africa. As for their predatory role in rice fields, the damselflies Ishnuera senegalensis, Agriocnemis pygmaea, Ishnuera delicata and Ceriagrion coromandelianum (Krishnasamay et al., 1983) were reported to be predating upon leaf- and planthoppers. They also reported the dragonflies Orthetrum Sabina, Crocothemis servilia, Pantala flavescens and Diplocodes nubulosa as effective predators of rice Lepidoptera. The present paper deals with the diversity of Odonata in rice ecosystem of Madurai, Tamil Nadu.

\section{Materials ANd Methods}

The diversity and relative abundance of Odonata was studied at the Wetlands of Agricultural College and Research Institute, Madurai, Tamil Nadu. The study area receives water from the Vaigai dam. The minimum and maximum temperatures of the experimental area were $28^{\circ} \mathrm{C}$ and $40^{\circ} \mathrm{C}$, respectively, during Kharif (2000). The average rainfall of study area recorded was $928 \mathrm{~mm}$. Four popular rice varieties, viz., MDU 5, ADT 36, ADT 39 and ADT 43 were used during this season. Each variety was replicated into two treatments namely weeded plots (all the weeds removed) and partially weeded plots (10 weeds allowed/ $\mathrm{m}^{2}$ ). The size of the experimental plot was $8 \times 6 \mathrm{~m}$. The collection of adult dragonflies and damselflies in rice canopy ecosystem was done with sweep net. The collected adults were sorted out into respective taxa based on taxonomic characters and number of individuals in each taxon recorded. Sampling was taken at weekly intervals and a total of nine samplings taken during Kharif (2000). In the present investigation, Jaccard coefficient index of similarity (Jaccard, 1908) was used to study the diversity of Odonata between weeded and partially weeded rice ecosystems.

Jaccard index $(C j)=j /(a+b-j)$

$\mathrm{j}=$ Number of taxa occurring in both samples A (weeded) and B (partially weeded)

$\mathrm{a}=$ Number of taxa in sample A (weeded) and

$b=$ Number of taxa in sample B (Partially weeded)

\section{Results}

The present study revealed that a total of 12 taxa of Odonata comprising of nine Anisoptera and three Zygoptera were recorded (Table 1). Among the Anisoptera, Pantala flavescens (Fabricius.), Diplocodes trivialis (Rambur), Crocothemis servilia (Drury) and Tramea limbata (Desjardins) were the dominant species. Other species, Orthetrum Sabina (Drury), Rhyothemis variegata (Linnaeus), Neurothemis tullia (Drury), Anax guttatus, and Trithemis sp. were recorded only at the tillering stage of the crop. Among the three species of Zygoptera, Agriocnemis femina femina Brauer was the dominant species than Agriocnemis pygmaea Rambur and Ishnura sp. The similarity statistics of dragonfly exhibited the similarity values between $0.77-0.88$ in the first week and showed greater diversity (0.50) during fourth, fifth, sixth, seventh and eighth weeks (Table 2). Damselfly registered higher diversity $(0.50)$ from the second week to seventh week. Both the dragonfly and damselfly exhibited 0.50 similarity index during the fourth week sampling. The present study revealed that the dragonfly showed perfect similarity in the first week while the damselfly registered perfect similarity in the last week. The diversity of both dragonfly and damselfly did not show variations between the varieties. The diversity of adults was more in partially weeded plot, which had 18 species of weed plants. Among them Echinochloa colonum, Cyperus rotundus, Cyperus iria, Cyperus difformis, Panicum repens and Bracharia mutica were dominant.

\section{Discussion}

This study indicates that $P$. flavescens (Fabricius.), D. trivialis (Rambur), C. servilia (Drury), T. limbata (Desjardin) and $A$. femina femina Brauer showed greater dominance in all the week samplings. This was in accordance with the statement of Shelton and Edward (1983) who stated that common species had more individuals than rare species and had the ability to 
Table 1. Relative abundance of Odonata in irrigated rice ecosystem.

\begin{tabular}{lll}
\hline & Weeded * & $\begin{array}{c}\text { Partially } \\
\text { weeded * }\end{array}$ \\
\hline $\begin{array}{l}\text { Zygoptera } \\
\text { Coenagrionidae }\end{array}$ & \\
1. Agriocnemis femina femina Brauer & 42 & 64 \\
2. Agriocnemis pygmaea Rambur & 16 & 22 \\
3. Ishnura sp. & 7 & 10 \\
& 65 & 96 \\
Anisoptera & & \\
Libellulidae & & \\
4. Pantala flavescens (Fabricius.) & 16 & 31 \\
5. Diplocodes trivialis (Rambur) & 14 & 24 \\
6. Crocothemis servilia (Drury) & 12 & 18 \\
7. Orthetrum sabina (Drury) & - & 5 \\
8. Trithemis sp. & 2 & 4 \\
9. Rhyothemis variegata (Linnaeus) & 4 & 6 \\
10. Neurothemis tullia (Drury) & 4 & 5 \\
Aeshnidae & & \\
11. Anax guttatus (Burmeister) & 2 & 12 \\
12. Tramea limbata (Desjardin) & 9 & 109 \\
* Values in the columns are the total & 63 & 4 \\
\hline
\end{tabular}

* Values in the columns are the total number of individuals collected during kharif 2000.

Table 2. Taxonomic similarity of Odonata between weeded and partially weeded rice ecosystems.

\begin{tabular}{|c|c|c|c|c|c|c|c|c|}
\hline \multirow[t]{2}{*}{ Fauna } & \multicolumn{4}{|c|}{ I week } & \multicolumn{4}{|c|}{ II week } \\
\hline & MDU5 & ADT36 & ADT39 & ADT43 & MDU5 & ADT36 & ADT39 & ADT43 \\
\hline Dragonfly & 0.88 & 0.77 & 0.83 & 0.80 & 0.71 & 0.75 & 0.75 & 0.75 \\
\hline Damselfy & 1.00 & 1.00 & 1.00 & 1.00 & 0.50 & 0.50 & 0.50 & 0.50 \\
\hline \multirow[t]{2}{*}{ Fauna } & \multicolumn{4}{|c|}{ III week } & \multicolumn{4}{|c|}{ IV week } \\
\hline & MDU5 & ADT36 & ADT39 & ADT43 & MDU5 & ADT36 & ADT39 & ADT43 \\
\hline Dragonfly & 0.60 & 0.66 & 0.71 & 0.66 & 0.57 & 0.50 & 0.50 & 0.50 \\
\hline Damselfy & 0.50 & 0.50 & 0.50 & 0.50 & 0.50 & 0.50 & 0.50 & 0.50 \\
\hline \multirow[t]{2}{*}{ Fauna } & \multicolumn{4}{|c|}{ V week } & \multicolumn{4}{|c|}{ VI week } \\
\hline & MDU5 & ADT36 & ADT39 & ADT43 & MDU5 & ADT36 & ADT39 & ADT43 \\
\hline Dragonfly & 0.50 & 0.50 & 0.50 & 0.50 & 0.50 & 0.50 & 0.50 & 0.50 \\
\hline Damselfy & 0.48 & 0.40 & 0.45 & 0.40 & 0.41 & 0.42 & 0.41 & 0.42 \\
\hline \multirow[t]{2}{*}{ Fauna } & \multicolumn{4}{|c|}{ VII week } & \multicolumn{4}{|c|}{ VIII week } \\
\hline & MDU5 & ADT36 & ADT39 & ADT43 & MDU5 & ADT36 & ADT39 & ADT43 \\
\hline Dragonfly & 0.50 & 0.50 & 0.50 & 0.50 & 0.50 & 0.50 & 0.50 & 0.50 \\
\hline Damselfy & 0.42 & 0.45 & 0.42 & 0.44 & 0.60 & 0.70 & 0.75 & 0.75 \\
\hline \multirow[t]{2}{*}{ Fauna } & \multicolumn{4}{|c|}{ IX week } & & & & \\
\hline & MDU5 & ADT36 & ADT39 & ADT43 & & & & \\
\hline Dragonfly & 1.00 & 1.00 & 1.00 & 1.00 & & & & \\
\hline Damselfy & 0.71 & 0.83 & 0.83 & 0.83 & & & & \\
\hline
\end{tabular}

* Values are Jaccard indices survive in existing environmental conditions. The Odonata showed greater diversity during successional age of the crop growth. This is probably due to canopy closure and availability of relative humidity and weed plants as suggested by Lawton (1983).

The adults of dragonfly and damselfly were present through out the season. But, neither showed higher diversity with reference to number of individuals. Hurd et al. (1971) stated that the abundance of one group of insects is to have little effect on the other species in a stable ecosystem. In the fourth week of sampling, both dragonfly and damselfly exhibited same level of similarity. Species of dragonfly and damselfly preferred tillerring stage of the diversified ecosystem because the canopy of weed plants and rice crop covered the entire surface area to create a favourable microclimate for the abundance of dragonfly and damselfly species. This is in consonance with the view of Mac Arthor (1965) who stated that the adjustment in species abundance is more in diversified ecosystem.

\section{REFERENCES}

Barrion, A.T. and J.A. Litsinger (1994). Taxonomy of rice insect pests and their Arthropod parasites and predators, pp.13-359. In: E.A. Heinrichs (Ed). Biology and Management of Rice Insects, .

Gunathilagaraj, K., R.P. Soundarajan, N. Chitra and M. Swamiappan (1999). Odonata in the rice fields of Coimbatore. Zoos' Print Journal 14(6): 43-44.

Hurd, L.E., M.V. Mellinger, I.L. Wolf and S.J. Mc Naughton (1971). Stability and diversity in three tropic levels in terrestrial successional ecosystem. Science 173: 1134-1136.

Jaccard, P. (1908). Nouvelles recherctus surla distribution floral. Bulletin Society Science Naturale 44: 223-270

Krishnasamy, N., O.P. Chautian and R.K. Das (1983). As some common predators of rice insect pests in Assam, India. IRRN 9(2): 1516.

Lawton, J.H. (1983). Plant architecture and the diversity of phytophagous insects. Annual Review of Entomology 28: 23-39.

Mac Arthor, R.H. (1965). Pattern of species diversity. Biological Review 40: $510-533$

Shelton, M.D. and C.R. Edwards (1983). Effect of weeds on the diversity and abundance of insects in soybeans. Environmental Entomology 12: 296-299.

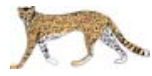

